\title{
The Subsidiarity Principle and National Parliaments Role: From Formal Need to Real Use of Powers
}

\author{
Ani Matei *(D) and Adrian Stelian Dumitru* \\ Faculty of Public Administration, National University of Political Studies and Public Administration, \\ 010643 Bucharest, Romania \\ * Correspondence: amatei@snspa.ro (A.M.); adystelian@yahoo.com (A.S.D.)
}

Received: 16 March 2020; Accepted: 15 April 2020; Published: 20 April 2020

\begin{abstract}
Subsidiarity constitutes a guiding principle of the EU exercising power and the idea of involving national parliaments in the EU legislative procedure was seen as the best solution to increase democracy and transparency of the EU decision-making process at the European Convention established in 2001. Such a mechanism enables national parliaments to ensure the correct application of the principle of subsidiarity by the institutions taking part in the legislative process. This article examines how this principle is implemented by the national parliaments and EU responsible institutions. What is the novelty derived from the Treaty of Lisbon? Do national parliaments participate actively in the implementation of subsidiarity? If yes, what are the tools at their disposal? To answer all of these questions we try to shape a framework for understanding the phenomenon.
\end{abstract}

Keywords: subsidiarity; national parliaments; early warning mechanism; EU competences; reasoned opinions

\section{Introductory Considerations}

In the past, the procedural dimension of subsidiarity has been the dominant perspective but the recent reforms have, consequently, aimed to strengthen this dimension by involving the national parliaments as the watchdogs of subsidiarity principle.

This article aims to examine the role of the national parliaments under the policy-making process after the Lisbon Treaty and their commitment to carry out their tasks. In the beginning we focus on the context and development of the subsidiarity principle in order to understand how this idea was introduced and what were the reasons for this.

After a brief overview of the subsidiarity principle meaning, in the second part we focus on national parliaments and their role as the legal provisions states. We look at both the ex-ante mechanism for the subsidiarity control as well as the category of competences subject to subsidiarity evaluation.

The last part, which has a core role for our research, analyzes the involvement of the national parliaments as a result of the subsidiarity principle application. We are interested to look at the numbers resulting from the entire process, reasoned opinions issued by member states and the top most active chambers by submitting reasoned opinions and general opinions to the Commission. We will briefly introduce an overall picture starting with the first reasoned opinion issued in 2010 and then we look in detail at reasoned opinions issued between 2016 and 2018. Furthermore, we try to identify the individual proposals and packages that received the greatest number of reasoned opinions in 2018 and the member states' implication on this matter.

In the final remarks we present the main findings of our work and try to provide some possible explanations to the current state of the application of the subsidiarity principle by national parliaments. 


\section{Context and Development of the Subsidiarity Principle}

The introduction of the principle of subsidiarity should be seen in this broader context of the evolution of the European integration process. The European Community (now EU) was deemed by some to attribute too many powers to itself or to neglect the federal entities existing in certain member states (Fromage 2017, p. 3). It made its first entrance into the EU Treaties with the 1986 Single European Act, but only in reference to environmental policy (art. 130). The Maastricht Treaty (art. 5 EC) "updated" the principle to a general principle of EC law, and thus became also liable for judicial review by the European Court of Justice, mainly owing to pressure from decentralized states and in particular by the United Kingdom and the German Länder (Van Nuffel 2011, p. 59). Since then it has become one of the fundamental principles of the EU (Lopatka 2019, p. 27).

Shortly after the approval of the Maastricht Treaty, the Council provided some guidance as to how the principle should be applied. For instance, it considered that applying this principle now contained in Article 3b of the EC Treaty would amount to asking the question: "Should the Community act?". It further spelt out the obligation for all (then) EC institutions to respect it and also insisted on the dual nature of this "dynamic principle", which could serve both to expand and to limit the EC's capacities to act in domains of shared competence (Fromage 2017, p. 3).

The 1993 Inter-institutional Agreement on Procedures for Implementing the Principle of Subsidiarity required all three institutions to have regard to the principle when devising Community legislation. This was reconfirmed by the Protocol on the Application of the Principles of Subsidiarity and Proportionality attached to the Amsterdam Treaty, which set out in more detail the subsidiarity calculus (Craig and de Búrca 2011, p. 94). Some authors argue that the very existence of Article 5 EC nonetheless had an impact on the existence and form of Community action. The European Commission considered whether action really was required at the Community level, and if this was so it would often proceed through directives rather than regulations (Craig and de Búrca 2011, p. 95).

However, at the time no specific link between subsidiarity and parliaments was made and it would have been hard to predict that this principle would gain the importance it has now acquired within the EU. In fact, there was a certain paradox in the introduction of the principle of subsidiarity, applicable only in areas of shared competence, at a time when there was no clear definition of the different types of competences (Fromage 2017, p. 3). This does not mean that the principle of subsidiarity was not taken into consideration by the Commission, but the absence of the definition of the exclusive competences hindered the achievability of all the objectives that had motivated the introduction of the principle (Fromage 2017, p. 3).

The 2007 Lisbon Treaty strengthened the principle in several ways by, for example, listing areas of exclusive competence, establishing the "early warning mechanism" (EWM) for national parliaments and by empowering the Committee of the Regions (CoR) to bring action for annulment on subsidiarity grounds.

The Lisbon Treaty also incorporated a sub-national dimension into the principle, by explicitly acknowledging that certain objectives may best be achieved at the regional or local levels. This is significant and may be taken to suggest that subsidiarity is no longer conceptualized as a binary principle to protect national prerogatives against EU interference (Tilindyte 2018, p. 9). Rather, it is an aspiration to take decisions as closely as possible to the citizen without, however, "jeopardizing win-win cooperation at the EU level" as Baldwin and Wyplosz (2015, p. 75) argue. Other considerations take into account the consolidation of member states' position by creating, indirectly, an obligation of the EU institutions to consider all state levels of organization in order to evaluate the subsidiarity. On the other hand, Gâlea (2012, p. 19) believes that listing all levels—central, regional and local-may lead to multi-layer governance, capable of gradually eroding the sovereignty concept by projecting competences both at the EU level and at regional and local levels.

It should be noted that the subsidiarity principle concerns the question as to whether this competence should be exercised. This reflects the implicit acknowledgment in the Treaties that EU competence, if given, need not automatically be acted upon. Logically, as we will see later, subsidiarity 
applies only to areas of non-exclusive Union competence (shared and supporting), where both the EU and member states may, in principle, take action. As only a few areas of Union action fall within the category of exclusive competence, most proposals will have to satisfy the subsidiarity test. However, certain "boundary disputes" regarding the delineation of competence are likely to arise, and actors may contest the categorization of competence as, for example, exclusive or shared.

Given the importance granted by the Lisbon Treaty to this issue, it contains a protocol on the application of the principles of subsidiarity and proportionality, which should be read in tandem with the Protocol on the Role of National Parliaments in the EU.

\section{National Parliaments and Their Role: EWM-An Innovative Tool}

It is important to mention that before the early 1990s, national parliaments had no official recognition in the institutional system (Wallace 2010, p. 87). Instead, national parliaments were typically the ones who ratified the treaties in the first place, who played an important role in calling to account national ministers as they negotiated directives in the Council, and who, in their legislative capacity, transposed directives into national law (Kiiver 2012, p. 536). However, Kiiver (2012, p. 536) notes that none of these roles were created or regulated by the treaties themselves: they derived, where applicable, from national constitutional law. Accordingly, these functions could, and still can, differ across member states.

Nevertheless, the need for national parliamentary scrutiny of EU policy provoked a large debate on this issue. As such, both the Treaty of the European Union and the Treaty of Amsterdam mention the importance of encouraging this, and the Treaty of Lisbon provides a mechanism for national parliaments to act when some proposals might be overly intrusive (Wallace 2010, p. 87).

Although in practice compliance of EU action-planned and adopted-with the principle of subsidiarity is considered at different phases by different actors-regulatory, political and judicial—probably the most prominent mechanism for this subsidiarity control, and one that has attracted impressive scholarly attention post-Lisbon, is the national parliaments' early warning mechanism (EWM).

Behind a relatively straightforward idea of the subsidiarity check system, this innovation looms as a system of great complexity. Kiiver (2012, p. 539) underscores that this system is not just a loose exchange of opinions between national parliaments and Brussels, but a legally formalized communication framework with rights and obligations, admissibility criteria and deadlines.

What does EWM mean? The introduction of the EWM by the Lisbon Treaty (Protocol no. 2 on the application of the principles of subsidiarity and proportionality) was significant insofar as it gave national parliaments a central role in watching over compliance of proposed legislation with the principle of subsidiarity. In the EWM, each national parliament may-within eight weeks of transmission of the proposal-issue a reasoned opinion, setting out why the national parliament (or chamber thereof) considers a proposal as violating subsidiarity.

Article 6 of Protocol no. 2 to the Treaty on European Union and the Treaty on the Functioning of the European Union on the application of the principles of subsidiarity and proportionality in fact contains five admissibility criteria for reasoned opinions. Thus, a reasoned opinion must:

(1) Originate in a national parliament or chamber thereof;

(2) Concern a draft legislative act of the EU;

(3) Be sent in time;

(4) Contain reasons; and

(5) Allege a violation of the principle of subsidiarity.

The European Commission must provide a detailed statement concerning proposed legislation so that compliance with subsidiarity can be appraised, known as the "Subsidiarity Sheet". The statement must contain some assessment of the financial impact of the proposals, and there should be qualitative and, wherever possible, quantitative indicators to substantiate the conclusion that the objective can 
be better attained at the Union level (Craig and de Búrca 2011, p. 96). The Commission must send all legislative proposals to the national parliaments at the same time as to the Union institutions. The national parliaments must also be provided with legislative resolutions of the European Parliament and positions adopted by the Council.

According to Article 3 of Protocol no. 2, a national parliament or chamber thereof may, within eight weeks, send the Presidents of the Commission, the European Parliament, and the Council a reasoned opinion as to why it considers that the proposal does not comply with subsidiarity. Each national parliament possesses two votes. In the bicameral parliamentary systems, each of the two chambers possesses one vote. Each chamber is entitled to issue reasoned opinions independently (Rozenberg 2017, p. 17).

In case the reasoned opinions represent at least a third of the total number of votes allocated to parliaments (currently 18 of the 56 votes), the proposal must be reviewed: the so-called "yellow card" (Tilindyte 2018, p. 9). The threshold falls to one quarter for a draft legislative proposal submitted on the basis of Article 76 TFEU (judicial cooperation in criminal matters and police cooperation). After the "yellow card" review, the Commission, however, remains free to maintain, amend or withdraw the proposal, but needs to justify why there is no infringement of the subsidiarity procedure. Where, in the context of the ordinary legislative procedure, reasoned opinions represent a simple majority of the votes allocated to national parliaments, an "orange card" is issued. This has not yet happened to date. After such a review the Commission may decide to maintain, amend or withdraw the proposal. If the Commission decides to maintain the proposal, it must justify its position and the matter is referred to the Union legislator.

The European Parliament and Council must then consider, before concluding the first reading, whether the proposal is compatible with the principle of subsidiarity. If the Parliament by a simple majority of its Members or the Council by a majority of $55 \%$ of its members consider that the proposal does not comply with the principle of subsidiarity, it is dropped. Specifically, in a case where a majority of national legislatures expresses a doubt on a subsidiarity matter and are not heard by the Commission, it will be easy for the Council or the European Parliament (EP) to delete the draft proposal (Rozenberg 2017, p. 18).

Therefore, while national parliaments lack the power to effectively veto a proposal by issuing a red card, such power rests with the EU legislator. It is worth mentioning that the issue of a red card was sought by David Cameron in November 2015 in the context of the "new settlement" for the UK in the EU before the UK referendum (Tilindyte 2018, p. 13). Arguably, the yellow and orange cards were intended to be relatively rare occurrences, a kind of "alarm bell" that only goes off when opposition to a proposal has reached such a high threshold that the normal legislative process should be disrupted (Cooper 2019, p. 7).

It is important to note that while the principle of subsidiarity applies generally to EU action in areas of non-exclusive competence, the EWM itself covers draft legislative acts only. Non-legislative acts, including delegated and implementing acts, are excluded from its application. However, there is nothing to prevent national parliaments from raising subsidiarity concerns regarding a legislative proposal that envisages the delegation of powers to the Commission to adopt delegated and implementing acts, and they have done so in the past (Tilindyte 2018, p. 13).

However, the most important political innovation related to the European institutional system is the incorporation of the national parliaments in it. The national parliaments are assigned, on one hand, the function of controlling the exercise of European competences and, on the other, the function of overseeing the transfer of new ones. The incorporation of the national parliaments into the European functioning represents an absolute novelty, well received by some, but doubtful for others, given the fears related to the functioning of the EU.

Supporters of this incorporation emphasize its contribution to increasing democratic control in the EU, its value in terms of EU legitimacy (Martín 2005, pp. 53-79; Cooper 2019, p. 9). As Cooper (2019, p. 9) points out, one optimistic view of the EWM was that it would make national parliaments a 
"virtual third chamber" within the EU's system of representative democracy alongside the Council and the European Parliament, performing the functions of an EU-level chamber without meeting in the same physical location. In an early paper, Cooper (2013) mentions that in this way the EWM could enhance the democratic legitimacy of the EU by providing a third channel of representation linking the citizen to the EU, which would in effect have a "tricameral" system for the representation of the EU's governments (Council), citizens (EP) and peoples (national parliaments). Detractors, for their part, argued on democratic grounds that national parliaments should not become EU-level actors because this blurs the existing lines of representation and accountability wherein it is only national governments that represent the member states at the EU level (Cooper 2019, p. 9). In addition, some have argued that an already slow decision-making process will be complicated and delayed without, in return, correcting the democratic deficit. That is because in their opinion, few national parliaments have an interest in the European polity (Davies 2003, pp. 686-98; Maurer 2003).

Wallace (2010, p. 88), in turn, believes that EU-level policy-makers are under increasing pressure to pay attention to national parliamentary discussions and appear more readily before national parliamentary committees of inquiry. The author expresses her opinion that this heightened sensitivity to country-level preoccupations is becoming a more marked feature of the European Union policy process.

The relevant role of the national parliaments in controlling subsidiarity is one of the main contributions of the constitutional debate around the definition of the European political model, but it is still difficult to evaluate it at this time. A priori, it seems that it will strengthen the democratic character of the Union and that, in addition, it could develop the cooperative character of European federalism through the participation of the member states not only at the governmental level, but also at the parliamentary level (Luzárraga and Guinea Llorente 2011, p. 181). Everything will depend, of course, on the national parliaments' interest in this activity and on their reaction speed, so that the strong sense represents the added value, the democratization of the system, and not the delay of the decision-making process (Luzárraga and Guinea Llorente 2011, p. 181).

\section{The Meaning of Subsidiarity}

Subsidiarity has emerged as a prominent concept and has a triple dimension: a philosophical, a political and a legal one (Bărbulescu 2015, p. 242). According to Schütze (2009, p. 525), in political philosophy, the principle of subsidiarity has historically come to represent the idea "that a central authority should have a subsidiary function, performing only those tasks that cannot be performed effectively at a more immediate or local level". The principle holds that the burden of argument lies with attempts to centralize authority (Follesdal 2011, p. 6). Reffering to this, Clergerie (1997, p. 5) states: "subsidiarity is the origin of many debates antagonizing those for whom it allows to take decisions closest to the citizens of which it, on the contrary, allows further tightening Eurocrats' powers in Brussels. It is true that it is rather a philosophical concept, not legal, which remains difficult to assess both in terms of content and its consequences".

Some scholars appeal to subsidiarity not only to negotiate centralization and diversity in EU law (de Búrca 1999) but also to determine the limits of sovereignty (Kumm 2009, p. 294). In an interesting piece of work, Follesdal (2011) analyzes different traditions of subsidiarity. Five subsidiarity interpretations are explored, drawn from Althusius, the US Federalists, Pope Leo XIII and others. The author argues that there are several versions of subsidiarity, with very different implications for the allocation of authority. They differ as to the objectives of the member units and the central authorities, the domain and roles of member units such as states, how they allocate the authority to apply the principle of subsidiarity itself and how they conceive of the relationship between different levels of political authority (Follesdal 2011, p. 9).

Follesdal (2011, p. 9) believes that the Lisbon subsidiarity shares some-but not all—weaknesses of what he calls "State Centric Subsidiarity", where states and their interests as traditionally conceived dominate other bodies and concerns. At least five aspects of the Lisbon Treaty underscore the prima facie preference for state authority over that of the EU. All five points illustrate why a principle of 
subsidiarity was explicitly introduced into the EU treaties starting with the Maastricht Treaty: member states sought to defend against unwarranted centralization and domination by Union authorities (Follesdal 2011, p. 18). We sum them up as follows:

- The Lisbon Treaty requires explicit consent by every EU member state (the competences and objectives of the EU are thus said to be identified, specified and conferred by member states);

- The Treaty states that where the states and the EU share authority, EU competences are to be exercised respectful of a principle of subsidiarity;

- The third example of subsidiarity in the Lisbon Treaty is the "Yellow Card Procedure" already assessed earlier;

- Inclusion of various human rights protections in the Lisbon Treaty makes a fourth example of subsidiarity;

- The fifth example of how the Lisbon Treaty expresses and respects subsidiarity concerns modifications to the EU's monitoring system for suspected human rights violations within member states (Follesdal 2011, pp. 18-20).

These five features of subsidiarity in the Lisbon Treaty illustrate different ways to regulate the allocation and use of authority. They all emphasize how the member states maintain their own authority and only suffer limited risks of domination by the central regional authorities.

It should be pointed out that subsidiarity has been part of Community law since its inception. Thus, the treaty establishing the European Coal and Steel Community (ECSC) referred to subsidiarity when ruling in Article 5 that the ECSC will fulfill its purpose under the conditions provided for in the treaty through "limited" interventions (Bărbulescu 2015, p. 242). The idea of its perpetuation is reinforced by Schütze's (2009, p. 526) assertion that the principle of subsidiarity "has remained a subsidiary principle of European constitutionalism", and that the reason for its shadowy existence lies in the continued absence of clear conceptual contours.

The subsidiarity principle applies to areas where the Union's competence is not exclusive. According to the Treaty on European Union (TEU), it require that "the Union shall act only if and in so far as the objectives of the proposed action cannot be sufficiently achieved by the Member States, either at central level or at regional and local level, but can rather, by reason of the scale or effects of the proposed action, be better achieved at Union level".

Certainly, the subsidiarity principle is applicable to the areas of shared competence. Although the TEU and the Treaty on the Functioning of the European Union (TFUE) do not expressly provide it, it is considered to be applicable to areas where the EU has competence to support, coordinate or complement the actions of the member states. In this case, although in substance the competence is of the member states, the EU has significant jurisdiction, with the possibility of action "above" the exercise of the powers of the states. Basically, in these areas, there is a "compatible overlap" of EU competence with the competence of the member states, configured by the substantial provisions regarding each policy (Gâlea 2012, p. 18).

Thus, in the areas of shared competence, after verification of subsidiarity, the EU acts "alone" (Gâlea 2012, p. 18). In the fields provided by Article 6 of the TFEU, the EU cannot act "alone", but can support, coordinate or complement the actions of states. However, in these areas, the Union's action in the absence of the exercise of the states' own powers is impossible.

Subsidiarity cannot exist in the area of exclusive Community competences, which does not mean that national, regional or local authorities cannot intervene at the levels close to the citizen they represent in order to carry out community action. Of course, the discussion on subsidiarity does not make sense in the case of exclusively national competences, but, according to the logic above, the EU and the member states ensure that common principles, values and commitments are respected.

Bărbulescu (2015, p. 241) notes that, like the 1984 Spinelli Construction Project, the TEU defines subsidiarity in terms of efficiency and supranationality. In other words, efficiency is not sufficient, but it must have a supranational scope and demand solutions at this level so that we can talk about 
subsidiarity. He also notes that subsidiarity should not be understood as a brake on the extension of EU competences, but on the contrary, as a legal basis for establishing the need to extend competences when state action is insufficient or when the expected size and effects cannot be satisfactorily achieved by state means (Bărbulescu 2015, p. 242).

\section{Analysis of the National Parliaments' Involvement as a Result of the Subsidiarity Principle Application}

Each year the European Commission submits, in line with Article 9 of Protocol no. 2 to the Treaty on European Union and to the Treaty on the Functioning of the European Union, an annual report on the application of the principles of subsidiarity and proportionality in European Union lawmaking. As such, we restrict our analysis to the annual reports on the application of the principle of subsidiarity, which provide valuable figures that have been examined in order to achieve a rigorous interpretation.

Before looking at the numbers, we must mention that a noteworthy development in 2018 was the work of the Task Force on Subsidiarity, Proportionality and "Doing less, more efficiently", set up by President Juncker and chaired by First Vice-President Timmermans, with the aim to ensure that EU legislation is developed and implemented in line with the principles of subsidiarity and proportionality (European Commission 2017a). The announcement of the creation of the task force was made in the State of the Union address, on 13 September 2017.

In his State of the Union Address, President Juncker said:

"This Commission has sought to be big on big issues and small on the small ones and has done so. To finish the work we started, I am setting up a Subsidiarity and Proportionality Task Force to take a very critical look at all policy areas to make sure we are only acting where the EU adds value". (European Commission 2017a)

The idea was based on the debate launched by the White Paper on the Future of Europe by 2025. One of the scenarios presented-Scenario 4-was "Doing less more efficiently" under which the European Union should step up its work in certain fields while stopping to act or doing less in domains where it is perceived as having more limited added value, or as being unable to deliver on its promises (European Commission 2017b).

As we mentioned above, in the EWM, each national parliament may issue a reasoned opinion, during the timeframe set, stating why the national parliament (or chamber thereof) considers a proposal as violating subsidiarity. In our analysis we are interested to find out the numbers of reasoned opinions or other opinions sent by national parliaments and whether the numbers are either ascending or descending compared with previous years. We chose to look in detail at available data corresponding to the years 2016-2018. This decision is founded not only on the fact that this period is somewhat of date; we also took into consideration that the number of reasoned opinions received in 2016 was the third highest in a calendar year since the subsidiarity control mechanism was introduced by the Lisbon Treaty in 2009. Additionally, 2016 saw a substantial increase compared to the previous year. Nevertheless, we will briefly introduce an overall picture starting with the first reasoned opinion issued, so that we have in mind the entire pathway that goes up to 2018.

Figure 1 presents an overview of the number of reasoned opinions compared to other opinions, since 2009, the year that marked the entry into force of the Lisbon Treaty. 


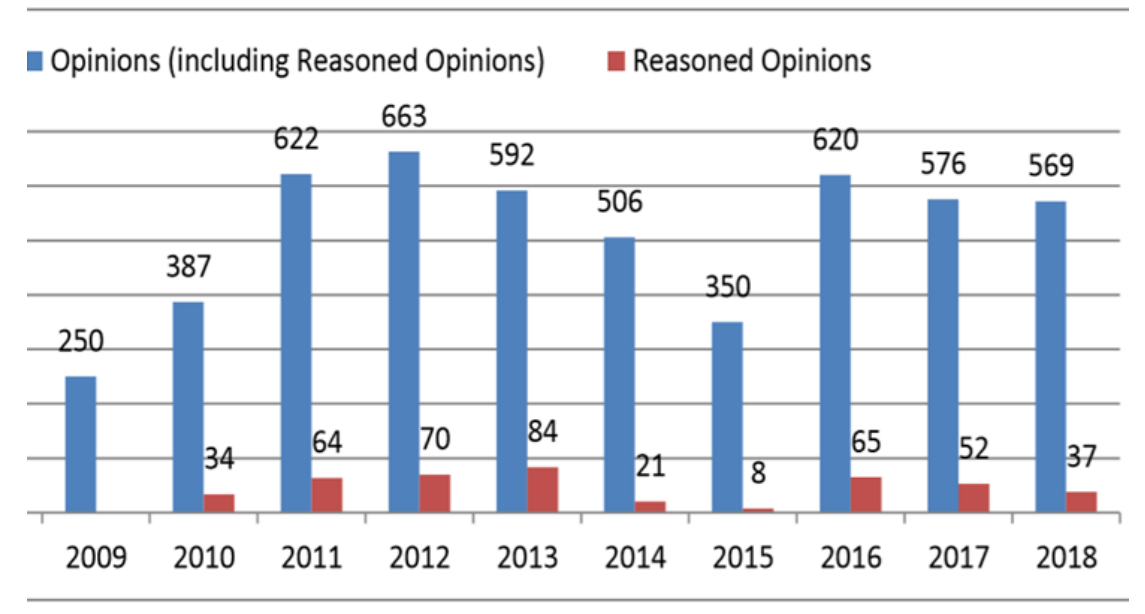

Figure 1. Overview of the number of reasoned opinions (ROs) compared to other opinions since 2009. Source: European Commission (2019, p. 16).

At first sight, the analysis of the annual output of reasoned opinions (ROs) shows a variable pattern. Whereas the EWM officially started on 1 December 2009 (the day the Treaty of Lisbon entered into force), the first ROs began to be issued in April 2010. As national parliaments adapted to the new system, the annual output of ROs increased steadily over the first four years, up to 2013. Then, the number of ROs fell sharply in 2014 and reached an all-time low in 2015. While some at the time interpreted this fall as evidence that the national parliaments had lost interest in the EWM, Cooper $(2019$, p. 5) believes that it proved to be a temporary lull, as the number of ROs rose again in 2016. However, we see the same decrease starting with 2017.

Cooper (2019, p. 5) mentions that the most likely explanation for the lull is that there was a fall in the output of new legislative proposals subject to the EWM in 2014-2015. This was in part due to the EP elections and the appointment of a new Commission in 2014, and in part because the new Commission made a commitment not to introduce too much new legislation early in its mandate. This might be also applicable for the decrease felt in 2018 considering that 2019 was an election year for Brussels and a new Commission was appointed in late 2019.

Coming back to recent years, in 2016 the European Commission received 65 reasoned opinions from national parliaments on the principle of subsidiarity. This was $713 \%$ more than the eight reasoned opinions received in 2015. The reasoned opinions received in 2016 also accounted for a higher proportion $(10.5 \%)$ of the total number of opinions received by the Commission in that year under the political dialogue (European Commission 2017c).

In 2017, the Commission received 52 reasoned opinions. This was $20 \%$ less than the 65 reasoned opinions received in 2016, corresponding to a lower overall number of opinions received in 2017. The proportion of reasoned opinions compared to the overall number of opinions received in 2017 also decreased to $9 \%$ in 2017 (European Commission 2018).

The downward trend continued in 2018 when the European Commission received 37 reasoned opinions from national parliaments (European Commission 2019). Regarding the overall number of opinions received in 2018, the numbers were almost the same as in previous years (620 in 2016, 576 in 2017,569 in 2018), meaning that the proportion of reasoned opinions compared to the overall number of opinions received continued to decrease, falling to 6.5\% in 2018 (European Commission 2019).

Figure 2 shows the number of reasoned opinions/other opinions issued by national parliaments between 2016 and 2018. 


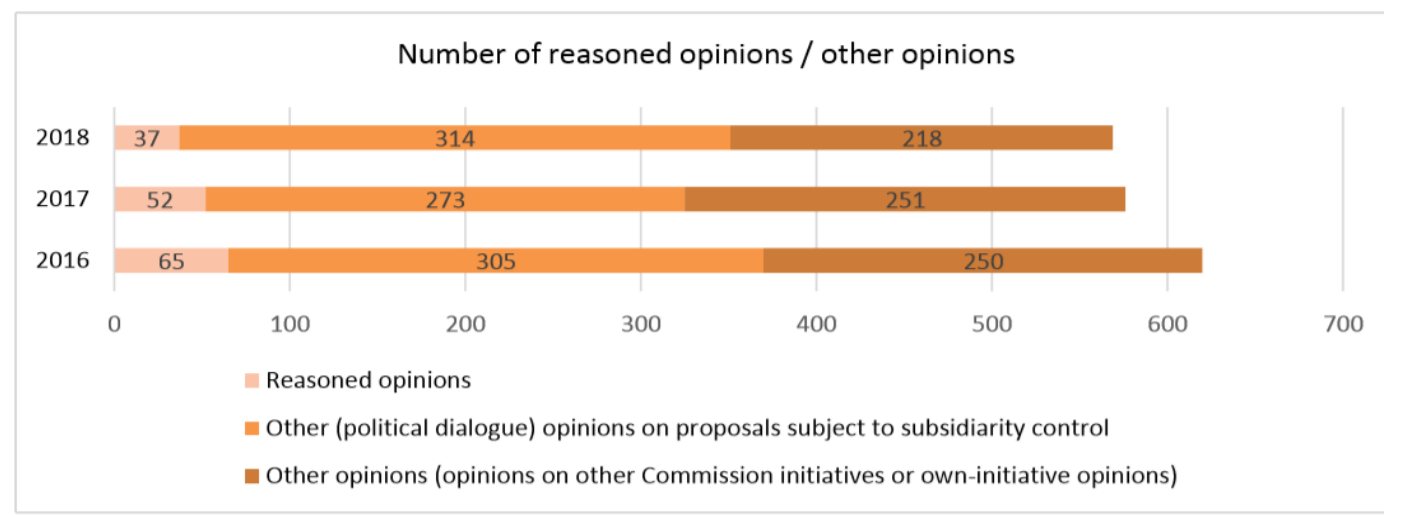

Figure 2. Number of reasoned opinions/other opinions issued by national parliaments between 2016 and 2018. Source: European Commission (2019, p. 12).

In order to understand the phenomena, we mention that the difference between the numbers of reasoned opinions and the overall numbers includes opinions on proposals subject to subsidiarity control (political dialogue) and opinions on other Commission initiatives or own-initiative opinions.

An interesting fact is that while reasoned opinions sent by national parliaments generally question the added value of the proposed action at the European level compared to action at the national, regional or local level, it is also worth mentioning that, conversely, the reasoned opinion issued by the French Assemblée Nationale on strategic plans under the common agricultural policy opposed excessive delegation of power to member states and found that the policy would be more effectively implemented at the EU level.

The decrease in the total number of reasoned opinions issued in 2018 reflected a similar decrease in the number of reasoned opinions issued per chamber. As such, only 14 out of 41 chambers issued reasoned opinions in 2018 (compared with 26 in 2016 and 19 in 2017).

Figure 3 illustrates the decrease in the number of reasoned opinions issued per chamber between 2016 and 2018.

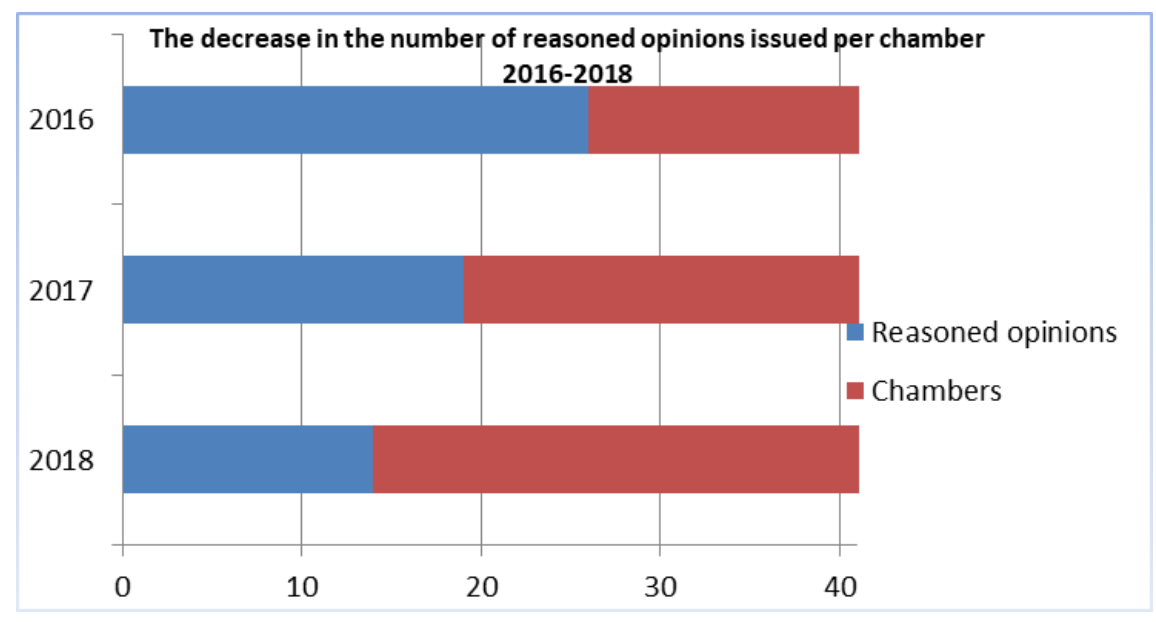

Figure 3. The decrease in the number of reasoned opinions issued per chamber (2016-2018). Source: own elaboration using information available in the annual report for 2018.

National parliaments expressed an increased interest in European decision-making in 2016, in particular as regards the subsidiarity control mechanism, with the number of reasoned opinions increasing from eight in 2015 to a total of 65 in 2016. Of these, 14 reasoned opinions related to the proposal for a targeted revision of the posting of the workers directive, triggering for the third time the procedure under Article 7(2) of Protocol no. 2 to the Treaties. This massive activity of national parliaments may be due to the importance of the legislative package in discussion. 
The arguments put forward by the national parliaments were widely debated, including at meetings of the Conference of Parliamentary Committees for Union Affairs (COSAC) and in the European Parliament's Committee on Legal Affairs and Committee on Employment and Social Affairs. Although the European Commission ultimately decided after these discussions and a thorough review of all the opinions received to maintain its initial proposal, it recognizes that a number of national parliaments remain unconvinced of its merits (European Commission 2017c).

Among the 52 reasoned opinions received in 2017, 24 opinions were concentrated on four Commission proposals (European Commission 2018). The proposal giving rise to most reasoned opinions was the proposal on the internal market for electricity, which generated 11 reasoned opinions. Two legislative proposals in the so-called "services package" received a total of nine reasoned opinions and the proposal on work-life balance for parents and caregivers received four reasoned opinions.

A novelty for 2017 was when the European Union legislator adopted for the first time a legislative proposal on which a so-called "yellow card" procedure had been triggered pursuant to Article 7(2) of Protocol no. 2 to the Treaties. This was the proposal for a Council Regulation establishing the European Public Prosecutor's Office (EPPO), which had been adopted by the Commission on 17 July 2013.

As such, in 2013 the Commission received 13 reasoned opinions from national parliaments on the proposal, representing 18 out of 56 possible votes, i.e., a quarter of the votes allocated to national parliaments (European Commission 2018). Among the concerns expressed in the reasoned opinions, the chambers argued that the European Commission had not sufficiently explained how the proposal complied with the principle of subsidiarity, that existing mechanisms in place in member states were sufficient and that no added value of the measures could be demonstrated (European Commission 2018). After confirming that the "yellow card" procedure had been triggered, the Commission carried out a review of the proposal. In particular, the Commission considered that the explanatory memorandum and the impact assessment sufficiently explained why action at the national level would not achieve the policy objective and why, by contrast, Union level action could achieve this. On that basis, the Commission decided to maintain the proposal (European Commission 2018).

The Council adopted a Regulation establishing the European Public Prosecutor's Office on 12 October 2017. It is interesting to note that the Regulation was adopted under the enhanced cooperation procedure by 16 out of the 28 member states (European Commission 2018). By the date of entry into force of the regulation, another six member states joined the enhanced cooperation. Four of the 11 member states whose parliamentary chambers had submitted reasoned opinions have so far not decided to participate in the enhanced cooperation (Hungary, Ireland, Sweden and the United Kingdom). Seven member states, whose parliamentary chambers had submitted reasoned opinions, namely Cyprus, Czech Republic, France, Malta, the Netherlands, Romania and Slovenia have joined the enhanced cooperation.

When it comes to individual proposals or packages that received the greatest number of reasoned opinions in 2018, we identified three proposals: the proposal on the revision of the Drinking Water Directive, the proposal for directives on the taxation of digital activities in the Union and the proposal for a regulation on streamlining measures for advancing the realization of the trans-European transport network.

The first proposal, which was intended to recast the directive on the quality of water intended for human consumption, gave rise to four reasoned opinions that came from the Austrian Bundesrat, the Czech Poslanecká Sněmovna, the Irish Dáil and Seanad Éireann and the British House of Commons (European Commission 2019). The European Commission also received four opinions in the context of the political dialogue, namely from the Czech Senát, the German Bundesrat, the Portuguese Assembleia da República and the Romanian Senat. They all supported measures at the Union level, but three of them-except the one from the Portuguese Assembleia da República-also raised some proportionality concerns.

Regarding the second proposal, we have to emphasize that on 21 of March 2018, the European Commission adopted a proposal for a directive laying down rules relating to the corporate taxation 
of a significant digital presence and a proposal for a directive on the common system of a digital services tax on revenues resulting from the provision of certain digital services. These directives formed parts of a package on the taxation of digital economy and aimed to tackle the problems posed by the current corporate tax framework not keeping pace with the new features of the digital sector (European Commission 2019).

These two proposals triggered four reasoned opinions, namely from the Danish Folketing, the Irish Dáil and Seanad Éireann, the Maltese Kamra tad-Deputati and the Dutch Tweede Kamer.

The third proposal that received the greatest number of reasoned opinions was the proposal for a regulation on streamlining measures for advancing the realization of the trans-European transport network. This proposal also gave rise to four reasoned opinions from the Czech Senát, the German Bundestag, the Irish Dáil and Seanad Éireann and the Swedish Riksdag. The European Commission also received three opinions in the context of the political dialogue, namely from the German Bundesrat, the French Assemblée Nationale and the Portuguese Assembleia da República, which also raised some concerns about the proportionality of the actions proposed (European Commission 2019).

The possibility of submitting reasoned opinions is an important consultative tool to be used. Even if the "yellow card" procedure cannot be initiated due to an insufficient number of actively participating states, there is still a chance that a clear indication of the problem will trigger self-reflection among the decision-makers and achieve the intended goal. However, the table below shows that not all chambers are using the potential enshrined within their rights equally.

Figure 4 shows the number of reasoned opinions (RO) issued per chamber from 2016 to 2018.

\begin{tabular}{|c|c|c|c|c|}
\hline \multirow{8}{*}{$\frac{\sqrt[2]{3}}{\frac{\Xi}{3}}$} & 2016 & 2017 & 2018 & $\begin{array}{l}\text { Total of } \\
\text { RO/chamber }\end{array}$ \\
\hline & Bulgarian Narodno sabranie (3) & & & 3 \\
\hline & Czech Senát (3) & & Czech Senát (1) & 4 \\
\hline & Czech Poslanecká sněmovna (4) & Czech Poslanecká sněmovna (1) & Czech Poslanecká sněmovna (4) & 9 \\
\hline & Danish Folketing (2) & & Danish Folketing (2) & 2 \\
\hline & Estonian Riigikogu (1) & & & 1 \\
\hline & & German Bundestag (6) & German Bundestag (2) & 8 \\
\hline & & German Bundesrat (3) & & 3 \\
\hline \multirow{6}{*}{ 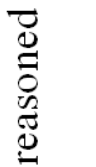 } & Irish Dáil Éireann (2) & Irish Dáil and Seanad Éireann (3) & Irish Dáil and Seanad Éireann (4) & 9 \\
\hline & Irish Seanad Éireann (1) & & & 8 \\
\hline & French Sénat (3) & French Sénat (7) & French Sénat (2) & 12 \\
\hline & & French Assemblée nationale (2) & French Assemblée nationale (1) & 3 \\
\hline & Croatian Hrvatski sabor (1) & & & 1 \\
\hline & Italian Senato della Repubblica (3) & Italian Senato della Repubblica (1) & Italian Senato della Repubblica (1) & 5 \\
\hline \multirow{5}{*}{ 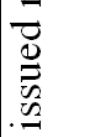 } & Latvian Saeima (1) & & & 1 \\
\hline & Lithuanian Seimas (1) & & & 1 \\
\hline & Luxembourg's Chambre des Députés (2) & & & 2 \\
\hline & Hungarian Országgyülés (2) & Hungarian Országgyülés (2) & & 4 \\
\hline & Maltese Kamra tad-Deputati (5) & & Maltese Kamra tad-Deputati (1) & 6 \\
\hline \multirow{13}{*}{ 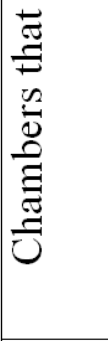 } & Dutch Eerste Kamer (1) & Dutch Eerste Kamer (2) & & 3 \\
\hline & Dutch Tweede Kamer (3) & Dutch Tweede Kamer (2) & Dutch Tweede Kamer (1) & 5 \\
\hline & Austrian Bundesrat (4) & Austrian Bundesrat (6) & Austrian Bundesrat (3) & 13 \\
\hline & Polish Senat (2) & Polish Senat (4) & & 6 \\
\hline & Polish Sejm (2) & Polish Sejm (2) & & 4 \\
\hline & Portuguese Assembleia da República (1) & & & 1 \\
\hline & Romanian Camera Deputaților (2) & Romanian Camera Deputaților (1) & & 3 \\
\hline & Romanian Senat (1) & Romanian Senat (2) & & 3 \\
\hline & Slovak Národná rada (2) & & & 2 \\
\hline & & Spanish Cortes Generales (2) & & 2 \\
\hline & Swedish Riksdag (12) & Swedish Riksdag (4) & Swedish Riksdag (12) & 28 \\
\hline & British House of Commons (1) & British House of Commons (2) & British House of Commons (2) & 5 \\
\hline & & & British House of Lords (1) & 1 \\
\hline Total/year & $65 \mathrm{RO}$ & $53 \mathrm{RO}$ & $37 \mathrm{RO}$ & \\
\hline $\begin{array}{l}\text { Percentage } \\
\text { of decrease } \\
\text { or increase }\end{array}$ & & & & \\
\hline
\end{tabular}

Figure 4. The number of reasoned opinions (RO) issued per chamber (2016-2018). Source: own elaboration based on information available in the annual reports of the European Commission for 2016, 2017 and 2018.

There are significant differences in the total number of reasoned opinions reported between individual years. Perkowski and Farhan (2019, p. 135) argue that this fact can be explained by the specificity of drafts sent to national parliaments in a given year, causing less doubt as to their compliance with the principle of subsidiarity. However, this fact cannot justify the disproportion in the number of reasoned opinions expressed in the chambers. 
As we see, in the period 2016-2018, the Swedish Riksdag returned a total of 28 opinions, followed by the Austrian Bundesrat and French Senat, while the Baltic States, Croatia, Portugal and others returned considerable less. In Perkowski and Farhan's (2019, p. 135) opinion, the consequence of this disparity reflects the varying degree of influence chambers have on EU affairs, i.e., "a large degree of influence in the case of chambers frequently submitting opinions and much less influence among those reporting them infrequently".

Concluding an interesting analysis of the Swedish Riksdag perception of subsidiarity, Cornell (2016, p. 316) remarks that the Swedish Riksdag perceives the scrutiny of subsidiarity primarily as a tool for safeguarding decentralization and for keeping itself updated regarding any competence overstretches on behalf of the EU legislator. Further, the author says that it is clear that the Swedish Committee on the Constitution-which has the task of observing general trends and providing a yearly report on the scrutiny by sectoral committees- "mainly considers itself as a gatekeeper whose main task is to identify any competence overstretch on behalf of the EU legislator within the area of shared competence between the EU and its member states, primarily by compiling the analysis made by sectoral committees" (Cornell 2016, p. 316).

When it comes to participation and scope, even more than in previous years, the number of general observations on the written opinions sent to the European Commission differed substantially between the national parliaments. According to the European Commission (2019, p. 16), the ten most active chambers-the Portuguese Assembleia da República (99 opinions-17\% of the total number of opinions received), the Czech Senát (81 opinions), the Spanish Cortes Generales (53 opinions), the German Bundesrat (52 opinions), the Romanian Camera Deputatilor (48 opinions), the Romanian Senat (45 opinions), the Czech Poslanecká Sněmovna (37 opinions), the French Sénat (24 opinions), the Italian Senato della Repubblica (18 opinions) and the Swedish Riksdag (15 opinions)—issued 472 opinions, i.e., 83\% of the total (2017: 74\% 2016: 73\%, 2015: 72\%), while 10 chambers, namely the Austrian Nationalrat, the Bulgarian Narodno Sabranie, the Cypriot Vouli ton Antiprosopon, the Estonian Riigikogu, the Finnish Eduskunta, the Greek Vouli ton Ellinon, the Latvian Saeima, the Luxembourg Chambre des Députés and the Slovenian Državni svet and Državni zbor issued no opinions.

Figure 5 presents the concentration of opinions sent to the European Commission by 10 most active chambers and other chambers.

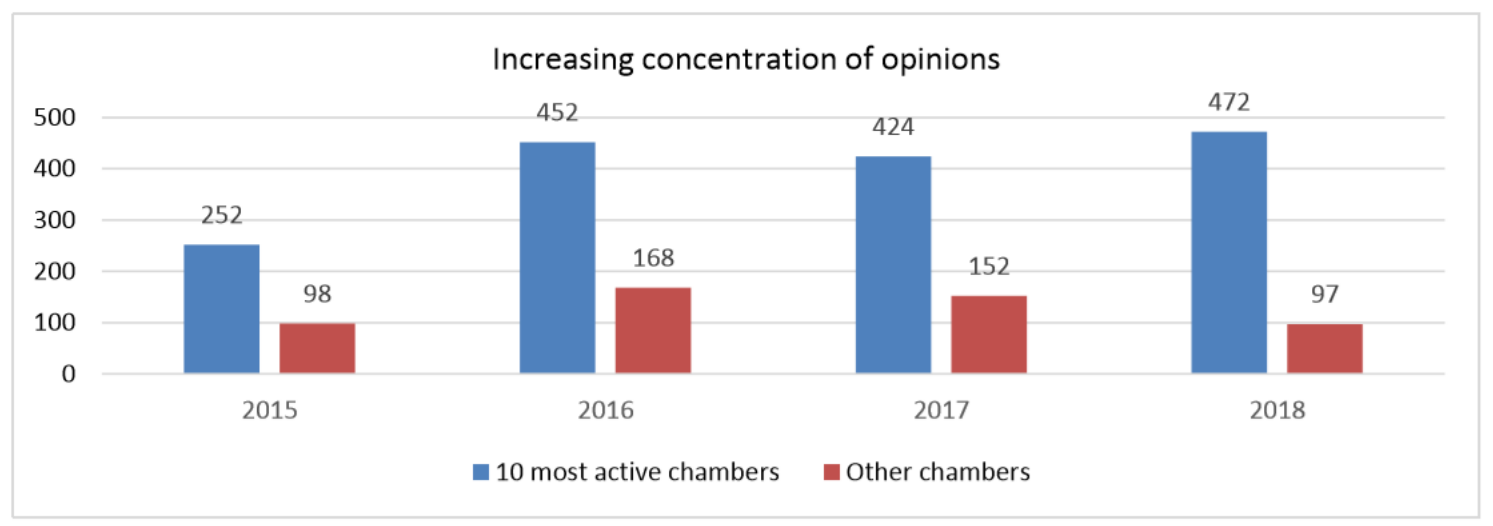

Figure 5. The number of opinions sent to the European Commission by the national parliaments (2015-2018). Source: European Commission (2019, p. 16).

\section{Final Remarks}

The Treaty of Lisbon modifies the categories of competences and therefore the common policies, redefines them and lists the principles on the basis of which their delimitation and exercise are achieved. We must remember that in Article 5 of the TEU the fundamental principles of "European power" are presented, the principle of conferral being the true source of EU competences, because that of subsidiarity and proportionality play the role of "guiding principles" of the exercise of EU powers. 
In addition to the exercise modalities defined in Article 5, as we have seen, there is the annexed protocol on the principles of subsidiarity and proportionality, which reinforces the control of the application of subsidiarity through the complementary mechanisms of political control (ex-ante) and respectively of legal control (ex-post). The protocol also includes the possibility that, during the implementation of the procedure of control of the application of the principle of subsidiarity by national parliaments, local or regional administrations may consult the regional parliaments in the case of the member states where they have legislative powers. The EWS is in itself an important instrument that guarantees that European competences will not overlap with national ones, unless such a measure is justified.

Regarding our analysis, its results showed that 2018 saw a significant decrease in the overall number of reasoned opinions received by the European Commission (37 compared to 52 in 2017 and 65 in 2016). This was against the background of a more or less stable number of legislative proposals presented by the Commission and an almost identical overall number of opinions received compared to 2017. Moreover, the reasoned opinions received covered various policy areas, and no single proposal triggered more than four reasoned opinions from national parliaments.

This could be the result of the European Commission applying a well-tested and even reinforced better regulation agenda and of its commitment to integrating the principles of subsidiarity and proportionality at all stages of policy-making, to evaluating existing policy frameworks before presenting legislative revisions and to initiating action at the European level only if its added value is clear (European Commission 2019, p. 27).

Regarding the number of opinions submitted by national parliaments as part of the political dialogue, it remained high in 2018 (569 opinions) and around the same as in 2017 (576) although, even more than in previous years, a few very active chambers accounted for a large part of these opinions. The relatively small proportion of reasoned opinions $(6.5 \%)$ and, conversely, the relatively high proportion of own-initiative opinions or opinions on non-legislative initiatives (38\%) compared to the total number of opinions submitted show national parliaments' continued interest in engaging with matters that go beyond the subsidiarity aspects of the European Commission initiatives and in providing valuable input as early as possible to the content of these initiatives. This might reflect the national parliaments' wish to be active in the European decision-making process in addition to influencing and controlling the European positions of their governments. Thus, it is possible to conclude that national parliaments have been somewhat less successful at blocking legislation than at influencing legislation though policy dialogue.

The principle of subsidiarity, and most importantly the introduction of the EWS, have certainly contributed to the enhancement of relations between national parliaments and EU institutions. However, this avenue for multi-level cooperation appears to be too narrow to satisfy national parliaments' thirst for being better involved in EU affairs. This is why the positive developments observed since the EWS has started to function cannot be detached from the broader context, and in particular from the added value ensured by the political dialogue in its written and non-written dimensions (Fromage 2017, p. 9).

Thereby, national parliaments are now active participants in the day-to-day legislative politics of the EU. These changes would encourage national parliaments to remain active participants in the EWS and the broader political dialogue and hopefully contribute to making it attractive to those who do not engage in this system at present.

Author Contributions: This article had been elaborated under the direct coordination and supervision of A.M. Research and conceptualization: A.S.D. All authors have read and agreed to the published version of the manuscript.

Funding: This research received no external funding.

Conflicts of Interest: The authors declare no conflict of interest. 


\section{References}

Baldwin, Richard, and Charles Wyplosz. 2015. The Economics of European Integration. New York: McGraw-Hill Education. Bărbulescu, Iordan Gheorghe. 2015. Noua Europă: Identitate şi Model European [The New Europe: Identity and European Model]. Iaşi: Polirom, vol. 1.

Clergerie, Jean-Louis Clergerie. 1997. Le Principe de Subsidiarite. Paris: Ellipses.

Cooper, Ian. 2013. Bicameral or Tricameral? National Parliaments and Representative Democracy in the European Union. Journal of European Integration 35: 531-46. [CrossRef]

Cooper, Ian. 2019. National Parliaments in the Democratic Politics of the EU: The Subsidiarity Early Warning Mechanism, 2009-2017. Comparative European Politics 17: 919-39. [CrossRef]

Cornell, Anna Jonsson. 2016. The Swedish Riksdag as Scrutiniser of the Principle of Subsidiarity. European Constitutional Law Review 12: 294-317. [CrossRef]

Craig, Paul, and Gráinne de Búrca. 2011. EU Law: Text, Cases, and Materials. (a V-a ed.). Oxford: Oxford University Press. Davies, Gareth. 2003. The post-Laeken division of competences. European Law Review 28: 686-98.

de Búrca, Gráinne. 1999. Reappraising Subsidiarity's Significance After Amsterdam. Jean Monnet Working Papers. Harvard Law School/NYU School of Law, no. 7/99. Available online: http://centers.law.nyu.edu/jeanmonnet/ papers/99/990701.html (accessed on 4 April 2020).

European Commission. 2017a. Press Release: Future of Europe: President Juncker Creates Task Force on 'Doing Less more Efficiently'. Brussels: European Commission.

European Commission. 2017b. White Paper on the Future of Europe. Reflections and Scenarios for the EU27 by 2025. COM(2017)2025. Brussels: European Commission.

European Commission. 2017c. Annual Report 2016 on the Application of the Principles of Subsidiarity and Proportionality. $\operatorname{COM}(2017) 600$ final. Brussels: European Commission.

European Commission. 2018. Annual Report 2017 on the Application of the Principles of Subsidiarity and Proportionality. $\operatorname{COM}(2018) 490$ final. Brussels: European Commission.

European Commission. 2019. Annual Report 2018 on the Application of the Principles of Subsidiarity and Proportionality and on Relations with National Parliaments. COM (2019) 333 final. Brussels: European Commission.

Follesdal, Andreas. 2011. The Principle of Subsidiarity as a Constitutional Principle in International Law. Jean Monnet Working Paper 12/11. Oslo: University of Oslo Faculty of Law, pp. 1-33. ISSN 2161-0320 (online).

Fromage, Diane. 2017. Subsidiarity as a Means to Enhance Cooperation Between EU Institutions and National Parliaments. Brussels: Policy Department for Citizens' Rights and Constitutional Affairs, European Parliament, vol. PE 583131.

Gâlea, Ion. 2012. Tratatele Uniunii Europene: Comentarii şi Explicaţii [Treaties of the European Union: Comments and Explanations]. Bucureşti: C.H. Beck.

Kiiver, Philipp. 2012. The conduct of subsidiarity checks of EU legislative proposals by national parliaments: Analysis, observations and practical recommendations. ERA Forum 12: 535-47. [CrossRef]

Kumm, Mattias. 2009. The cosmopolitan turn in constitutionalism: On the relationship between constitutionalism in and beyond the state. In Ruling the World? Constitutionalism, International Law, and Global Governance. Edited by Jeffrey L. Dunoff and Joel P. Trachtman. Cambridge: Cambridge University Press.

Lopatka, Reinhold. 2019. Subsidiarity: Bridging the gap between the ideal and reality. European View 18: 26-36. [CrossRef]

Luzárraga, Francisco Aldecoa, and Mercedes Guinea Llorente. 2011. Europa Viitorului: Tratatul de la Lisabona [The Future Europe: The Lisbon Treaty]. Iași: Polirom.

Martín, Araceli. 2005. El control del principio de subsidiariedad. In La Constitucionalizacion del Proceso de Integratíon Europea, Colecctión Escuela Diplomática no 9; Madrid: M. Asuntos Exteriores, pp. 53-79.

Maurer, Andreas. 2003. From the Eu Constitutional Convention to the Intergovernmental Conference. The Balance between Constitutional Principles and National Preferences. SWP Comments no 8. Berlin: German Institute for International and Security Affairs.

Perkowski, Maciej, and Jakub A. Farhan. 2019. Strengthening the role of national parliaments in the European Union-What for and how? Studies in Logic, Grammar and Rhetoric 59. [CrossRef]

Rozenberg, Olivier. 2017. The Role of National Parliaments in the EU after Lisbon: Potentialities and Challenges, European Parliament, Policy Department for Citizens' Rights and Constitutional Affairs, Directorate-General for Internal Policies. Brussels: European Union. 
Schütze, Robert. 2009. Subsidiarity after Lisbon: Reinforcing the safeguards of federalism? Cambridge Law Journal 68: 525-36. [CrossRef]

Tilindyte, Laura. 2018. Subsidiarity: Mechanisms for Monitoring Compliance. Brussels: European Parliamentary Research Service, PE 625.124.

Van Nuffel, P. 2011. The protection of Member States' regions through the subsidiarity principle. In The Role of the Regions in EU Governance. Edited by C. Panara. Berlin/Heidelberg: Springer, pp. 55-80.

Wallace, Hellen. 2010. An Institutional Anatomy and Five Policy Modes. In Policy-Making in the European Union, 6th ed. Edited by Hellen Wallace, Mark A. Pollack and Alasdair R. Young. Oxford: Oxford University Press, pp. 45-66.

(C) 2020 by the authors. Licensee MDPI, Basel, Switzerland. This article is an open access article distributed under the terms and conditions of the Creative Commons Attribution (CC BY) license (http://creativecommons.org/licenses/by/4.0/). 